\title{
STUDI KOMPARATIF : KINERJA KEUANGAN PEMERINTAH DAERAH SARBAGITA DENGAN KINERJA KEUANGAN PEMERINTAH PROVINSI BALI
}

\author{
Ni Putu Novianti Wira Adnyani ${ }^{1}$ \\ Ni Luh Putu Wiagustini \\ ${ }^{1,2}$ Fakultas Ekonomi dan Bisnis Universitas Udayana,Bali,Indonesia \\ e-mail: novianti.wira@yahoo.co.id
}

\begin{abstract}
ABSTRAK
Penerapan sistem otonomi daerah menuntut aparat pemerintah daerah untuk mampu mengelola keuangan di daerahnya secara efektif dan efisien. Tujuan dari penelitian ini yaitu : untuk menjelaskan perbandingan dan signifikansi perbedaan antara kinerja keuangan pemerintah daerah kota Denpasar, kabupaten Badung, kabupaten Gianyar dan kabupaten Tabanan dengan kinerja keuangan pemerintah provinsi Bali selama tahun 2011-2015 dari sisi kemandirian keuangan daerah, DDF, efektivitas PAD, pertumbuhan PAD, keserasian belanja dan efisiensi belanja. Hasil dari penelitian ini adalah kinerja keuangan pemeritah daerah kota Denpasar lebih unggul dibandingkan dengan kinerja keuangan pemerintah provinsi Bali dari sisi efektivitas PAD, pertumbuhan PAD dan keserasian belanja. Kinerja keuangan pemerintah daerah kabupaten Badung unggul dibandingkan dengan kinerja keuangan pemerintah provinsi Bali dari semua rasio kecuali rasio efisiensi belanja. Kinerja keuangan pemerintah daerah kabupaten Gianyar unggul dibandingkan dengan kinerja keuangan pemerintah provinsi Bali dari sisi efektivitas PAD, pertumbuhan PAD dan keserasian belanja, Kinerja keuangan pemerintah daerah kabupaten Tabanan unggul dibandingkan dengan provinsi Bali dari sisi efektivitas PAD dan pertumbuhan PAD.
\end{abstract}

Kata kunci : kinerja keuangan daerah

\begin{abstract}
The implementation of the regional autonomy system requires local government officials to be able to manage finances in their regions effectively and efficiently. The purpose of this research is to explain the comparison and significance of the difference between the financial performance of Denpasar city government, Badung regency, Gianyar and Tabanan districts with the financial performance of Bali provincial government during 2011-2015 in terms of regional financial independence, DDF, PAD effectiveness, growth of $P A D$, the compatibility of spending and expenditure efficiency. The result of this research is the financial performance of Denpasar city government is superior compared to the financial performance of Bali provincial government from the effectiveness of PAD, the growth of PAD and the harmony of expenditure. The financial performance of the local government of Badung district is superior compared to the Balinese provincial government's financial performance of all ratios except the expenditure efficiency ratio. The financial performance of the Gianyar district government is superior to the financial performance of the provincial government of Bali in terms of PAD effectiveness, PAD growth and harmonized spending. The financial performance of Tabanan district government is superior compared to Bali province in terms of PAD effectiveness and PAD growth.
\end{abstract}

Keywords: regional financial performance 


\section{PENDAHULUAN}

Penerapan sistem otonomi daerah tidak hanya dapat meningkatkan kemandirian pemerintah daerah, tetapi hal tersebut juga turut dapat mempengaruhi tingkat pertumbuhan perekonomian di suatu negara. Penelitian yang dilakukan oleh Rosemary et al. (2016) menunjukkan hasil bahwa penerapan sistem otonomi di negara Brazil lebih baik dibandingkan dengan negara Nigeria yang ditunjukkan oleh tingkat pertumbuhan ekonomi di negara Brazil yang lebih tinggi dari negara Nigeria.

Dalam menjalankan urusan daerahnya pada penerapan sistem otonomi daerah tentu yang menjadi sumber dana utama bagi pemerintah adalah pajak atau retribusi yang dipungut dari masyarakat. Penting bagi masyarakat utuk memastikan bahwa pajak atau retribusi yang dipungut dari masyarakat telah dipergunakan dengan baik oleh pemerintah. Salah satu upaya yang dapat dilakukan masyarakat adalah dengan melakukan penilaian terhadap kinerja keuangan pemerintah.

Penilaian terhadap kinerja keuangan pemerintah daerah dapat dilakukan dengan melihat laporan keuangan yang diterbitkan oleh pemerintah daerah di setiap tahunnya sebagai objek analisis dan rasio-rasio keuangan sebagai alat analisis. Salah satu laporan keuangan pemerintah daerah yang dapat dijadikan sebagai objek penilaian yaitu APBD. Mahmudi (2010:16-17) mengungkapkan bahwa, terdapat tiga komponen penting dalam APBD yang dapat dijadikan objek penilaian kinerja keuangan daerah yaitu pendapatan daerah, belanja daerah dan pembiayaan daerah. 
Sumber-sumber pendapatan daerah yaitu: PAD, transfer pemerintah pusat, transfer pemerintah provinsi serta lain-lain pendapatan yang sah. Pevcin (2012) dalam penelitiannya menemukan hasil bahwa transfer pendapatan berpengaruh positif signifikan terhadap upaya pajak di negara Slovenia. Komponen belanja daerah terdiri atas belanja operasi dan belanja modal (Mahmudi, 2010:88-89). Amuka et al. (2016) mengemukakan dalam penelitiannya bahwa tidak semua belanja pemerintah baik untuk stabilitas ekonomi. Pada penelitian yang dilakukan oleh Patricia dan Izuchukwu (2013), belanja pendidikan yang dilakukan oleh pemerintah Nigeria (Total Government Expenditure on Education-TEDU) memiliki pengaruh yang positif signifikan terhadap produk domestik bruto (PDB).

Frank dan Ishmaell (2014) mengemukakan bahwa, belanja berulang yang dilakukan oleh pemerintah Ghana berpengaruh positif terhadap pertumbuhan ekonomi di negara Ghana. Penelitian yang dilakukan oleh Udoka dan Anyingang (2015) juga turut menunjukkan bahwa pengeluaran keseluruhan yang dilakukan oleh pemerintah Nigeria memiliki dampak positif terhadap pertumbuhan ekonomi dan pembangunan perekonomian di Nigeria. Doh-Nani dan Awunyo-Vitor (2012) dalam penelitiannya mengemukakan bahwa antara belanja dan pendapatan yang dimiliki oleh negara Ghana saling berhubungan satu sama lain.

Nwosu dan Okafor (2014) yang membuktikan bahwa antara belanja pemerintah dengan pendapatan pemerintah di negara Nigeria memiliki hubungan yang searah. Kayode et al. (2015) menyatakan bahwa, belanja modal, belanja berulang, pendapatan di sektor minyak dan non minyak, federasi akun dan federasi saldo pendapatan berpengaruh positif terhadap pertumbuhan ekonomi di 
negara Nigeria. Aydin et al. (2016) dalam penelitiannya menyatakan bahwa, belanja pemerintah yang berada di atas ambang batas (government spending above the threshold) berpengaruh positif terhadap pertumbuhan ekonomi di negara Turki sementara untuk belanja pemerintah yang berada di bawah ambang batas (government spending below the threshold) berpengaruh negatif terhadap pertumbuhan ekonomi di negara Turki.

Hasil berbeda ditemukan oleh Egbetunde dan Fasanya (2014) dalam penelitiannya yang menemukan bahwa belanja publik yang dilakukan oleh pemerintah negara Nigeria berpengaruh negatif terhadap pertumbuhan ekonomi di Nigeria. Adefeso (2016) yang menyebutkan bahwa, belanja pemerintah berpengaruh negatif terhadap pertumbuhan ekonomi pada 20 negara di sub-Sahara Afrika. Venkataraman dan Urmi (2017) menjelaskan dalam penelitiannya bahwa, belanja modal yang dilakukan oleh pemerintah akan sangat ditentukan oleh besar kecilnya pendapatan yang diterima oleh masyarakat. Fasoranti (2012) dalam penelitiannya menyatakan bahwa, pembangunan infrastruktur memainkan peranan penting dalam penyelengaaran pemerintahan di suatu negara.

Nurlis (2016) dalam penelitiannya menemukan hasil bahwa pendapatan per kapita berpengaruh positif pada belanja modal, kepadatan penduduk berpengaruh positif terhadap alokasi belanja modal, GDP berpengaruh positif terhadap belanja modal dan PAD berpengaruh negatif terhadap belanja modal. Pada penelitian Sumawan dan Sukartha (2016) ditemukan hasil bahwa pajak daerah berpengaruh negatif pada kinerja belanja pemerintah daerah kabupaten atau kota di provinsi Bali sementara, retribusi daerah dan opini audit BPK tidak berpengaruh pada 
kinerja belanja pemerintah daerah kabupaten atau kota di provinsi Bali. Dalam penelitian ini rasio keuangan yang digunakan untuk menilai kinerja keuangan pemerintah daerah yaitu : rasio kemandirian keuangan daerah, rasio DDF, rasio efektivitas $\mathrm{PAD}$, rasio pertumbuhan $\mathrm{PAD}$, rasio keserasian belanja dan rasio efisiensi belanja.

Martini dan Dwirandra (2015), dalam penelitiannya menemukan hasil bahwa rasio efektivitas PAD berpengaruh positif namun tidak signifikan pada alokasi belanja modal. Penelitian terkait dengan kinerja keuangan daerah pernah dilakukan sebelumnya oleh Muliastini dan Yadnyana (2013) yang menggunakan objek studi pada kawasan metropolitan SARBAGITA (Denpasar, Badung, Gianyar dan Tabanan) tahun 2007-2011. Sijabat dkk. (2014) yang menggunakan objek studi pada dinas pendapatan daerah dan badan pengelola keuangan dan aset daerah kota Malang tahun anggaran 2008-2012. Mokodompit dkk. (2014) dalam penelitiannya yang berlokasi di kota Kotamobagu tahun anggaran 2011-2012.

Fitriani dan Dwirandra (2014) dalam penelitiannya yang berlokasi di seluruh kabupaten atau kota di provinsi Bali pada tahun 2007-2011. Oktavianus dkk. (2015) pada kota Bitung dan kota Tomohon periode anggaran 2010-2014 Saputra dkk. (2016) juga turut melakukan penelitian mengenai kinerja keuangan daerah yang belokasi di kabupaten Jembrana dan dilakukan pada tahun 20102014. Rahmawati dan Putra (2016) yang berlokasi di kabupaten Sumbawa pada tahun anggaran 2010-2012 serta Susilowati dkk. (2016) yang berlokasi di kabupaten Karanganyar pada tahun anggaran 2013-2015. Penelitian ini akan 
membahas lebih lebih lanjut mengenai kinerja keuangan daerah kabupaten atau kota di provinsi Bali pada tahun anggaran 2011-2015.

Gambar 1 berikut menyajikan data mengenai besarnya persentase PAD dari total pendapatan daerah pada kabupaten dan kota di provinsi Bali.

\section{Gambar 1.}

Persentase PAD Dari Total Pendapatan Daerah Kabupaten dan Kota Provinsi Bali Tahun 2011-2015

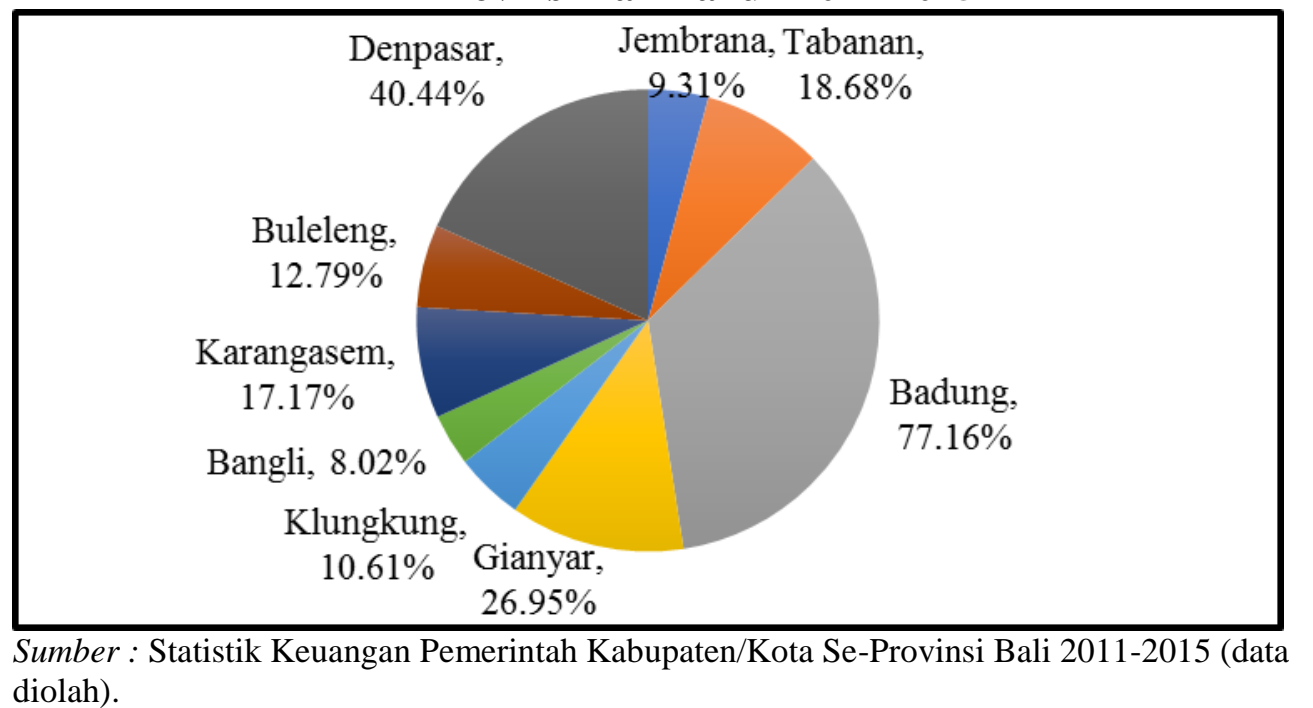

Gambar 1, menunjukkan bahwa kabupaten Badung memiliki tingkat persentase PAD paling tinggi sebesar 77,16 persen, diikuti oleh kota Denpasar dengan tingkat persentase sebesar 40,44 persen. Kabupaten Gianyar berada di urutan ketiga dengan tingkat persentase PAD dalam pendapatan daerahnya sebesar 26,95 persen dan kabupaten Tabanan yang tingkat persentase PAD sebesar 18,65 persen. Keempat wilayah tersebut memiliki jumlah PAD yang lebih tinggi dibandingkan dengan wilayah lainnya. Baik atau buruknya kinerja keuangan pemerintah daerah dinilai dari 2 sisi yaitu dari sisi pendapatan daerah dan juga belanja daerah. 
Tujuan penelitian ini yaitu untuk menjelaskan perbandingan dan signifikansi perbedaan antara kinerja keuangan pemerintah daerah SARBAGITA dengan kinerja keuangan pemerintah provinsi Bali selama tahun 2011-2015 dari sisi kemandirian keuangan daerah, DDF, efektivitas PAD, pertumbuhan PAD, keserasian belanja dan efisiensi belanja.

\section{TELAAH LITERATUR DAN PENGEMBANGAN HIPOTESIS}

Pengukuran kinerja keuangan sektor publik dalam penelitian ini menggunakan rasio kemandirian keuangan daerah, rasio DDF, rasio pertumbuhan PAD, rasio efektivitas $\mathrm{PAD}$, rasio keserasian belanja dan rasio efisiensi belanja. Penelitian ini juga turut menggunakan teknik uji independent sample t-test antara kinerja keuangan pemerintah daerah wilayah SARBAGITA dengan kinerja keuangan pemerintah provinsi Bali. Adapun hipotesis yang dirumuskan adalah sebagai berikut :

$\mathrm{H}_{1}$ : Terdapat perbedaan antara kinerja keuangan daerah kota Denpasar dengan kinerja keuangan daerah provinsi Bali.

$\mathrm{H}_{1.1}$ : Terdapat perbedaan antara kinerja keuangan daerah kota Denpasar dengan kinerja keuangan daerah provinsi Bali dari sisi kemandirian keuangan daerah.

$\mathrm{H}_{1.2}$ : Terdapat perbedaan antara kinerja keuangan daerah kota Denpasar dengan kinerja keuangan daerah provinsi Bali dari sisi DDF.

$\mathrm{H}_{1.3}$ : Terdapat perbedaan antara kinerja keuangan daerah kota Denpasar dengan kinerja keuangan daerah provinsi Bali dari sisi efektivitas PAD. 
$\mathrm{H}_{1.4}$ : Terdapat perbedaan antara kinerja keuangan daerah kota Denpasar dengan kinerja keuangan daerah provinsi Bali dari sisi pertumbuhan PAD.

$\mathrm{H}_{1.5}$ : Terdapat perbedaan antara kinerja keuangan daerah kota Denpasar dengan kinerja keuangan daerah provinsi Bali dari sisi keserasian belanja.

$\mathrm{H}_{1.6}$ : Terdapat perbedaan antara kinerja keuangan daerah kota Denpasar dengan kinerja keuangan daerah provinsi Bali dari sisi efisiensi belanja.

$\mathrm{H}_{2}$ : Terdapat perbedaan antara kinerja keuangan daerah kabupaten Badung dengan kinerja keuangan daerah provinsi Bali .

$\mathrm{H}_{2.1}$ : Terdapat perbedaan antara kinerja keuangan daerah kabupaten Badung dengan kinerja keuangan daerah provinsi Bali dari sisi kemandirian keuangan daerah

$\mathrm{H}_{2.2}$ : Terdapat perbedaan antara kinerja keuangan daerah kabupaten Badung dengan kinerja keuangan daerah provinsi Bali dari sisi DDF.

$\mathrm{H}_{2.3}$ : Terdapat perbedaan antara kinerja keuangan daerah kabupaten Badung dengan kinerja keuangan daerah provinsi Bali dari sisi efektivitas PAD.

$\mathrm{H}_{2.4}$ : Terdapat perbedaan antara kinerja keuangan daerah kabupaten Badung dengan kinerja keuangan daerah provinsi Bali dari sisi pertumbuhan PAD

$\mathrm{H}_{2.5}$ : Terdapat perbedaan antara kinerja keuangan daerah kabupaten Badung dengan kinerja keuangan daerah provinsi Bali dari sisi keserasian belanja.

$\mathrm{H}_{2.6}$ : Terdapat perbedaan antara kinerja keuangan daerah kabupaten Badung dengan kinerja keuangan daerah provinsi Bali dari sisi efisiensi belanja. 
$\mathrm{H}_{3}$ : Terdapat perbedaan antara kinerja keuangan daerah kabupaten Gianyar dengan kinerja keuangan daerah provinsi Bali

$\mathrm{H}_{3.1}$ : Terdapat perbedaan antara kinerja keuangan daerah kabupaten Gianyar dengan kinerja keuangan daerah provinsi Bali dari sisi kemandirian keuangan daerah.

$\mathrm{H}_{3.2}$ : Terdapat perbedaan antara kinerja keuangan daerah kabupaten Gianyar dengan kinerja keuangan daerah provinsi Bali dari sisi DDF.

$\mathrm{H}_{3.3}$ : Terdapat perbedaan antara kinerja keuangan daerah kabupaten Gianyar dengan kinerja keuangan daerah provinsi Bali dari sisi efektivitas PAD.

$\mathrm{H}_{3.4}$ : Terdapat perbedaan antara kinerja keuangan daerah kabupaten Gianyar dengan kinerja keuangan daerah provinsi Bali dari sisi pertumbuhan PAD.

$\mathrm{H}_{3.5}$ : Terdapat perbedaan antara kinerja keuangan daerah kabupaten Gianyar dengan kinerja keuangan daerah provinsi Bali dari sisi keserasian belanja.

$\mathrm{H}_{3.6}$ : Terdapat perbedaan antara kinerja keuangan daerah kabupaten Gianyar dengan kinerja keuangan daerah provinsi Bali dari sisi efisiensi belanja.

$\mathrm{H}_{4}$ : Terdapat perbedaan antara kinerja keuangan daerah kabupaten Tabanan dengan kinerja keuangan daerah provinsi Bali.

$\mathrm{H}_{4.1}$ : Terdapat perbedaan antara kinerja keuangan daerah kabupaten Tabanan dengan kinerja keuangan daerah provinsi Bali dari sisi kemandirian keuangan daerah.

$\mathrm{H}_{4.2}$ : Terdapat perbedaan antara kinerja keuangan daerah kabupaten Tabanan dengan kinerja keuangan daerah provinsi Bali dari sisi DDF. 
$\mathrm{H}_{4.3}$ : Terdapat perbedaan antara kinerja keuangan daerah kabupaten Tabanan dengan kinerja keuangan daerah provinsi Bali dari sisi efektivitas PAD

$\mathrm{H}_{4.4}$ : Terdapat perbedaan antara kinerja keuangan daerah kabupaten Tabanan dengan kinerja keuangan daerah provinsi Bali dari sisi pertumbuhan PAD

$\mathrm{H}_{4.5}$ : Terdapat perbedaan antara kinerja keuangan daerah kabupaten Tabanan dengan kinerja keuangan daerah provinsi Bali dari sisi keserasian belanja.

$\mathrm{H}_{4.6}$ : Terdapat perbedaan antara kinerja keuangan daerah kabupaten Badung dengan kinerja keuangan daerah provinsi Bali dari sisi efisiensi belanja.

\section{METODE PENELITIAN}

Penelitian ini dilakukan di kota Denpasar, kabupaten Badung, kabupaten Gianyar, kabupaten Tabanan dan provinsi Bali. Objek dari penelitian ini yaitu : kinerja keuangan daerah di masing-masing wilayah penelitian selama tahun 20112015. Sumber data dari penelitan ini yaitu : laporan statistik keuangan daerah kabupaten atau kota se-Bali tahun 2010-2014, laporan statistik keuangan daerah kabupaten atau kota se-Bali tahun 2011-2015, PERDA Provinsi Bali No. 8 Tahun 2011, PERDA Provinsi Bali No. 7 Tahun 2012, PERDA Provinsi Bali No. 7 Tahun 2013, PERDA Provinsi Bali No. 7 Tahun 2014, PERDA Provinsi Bali No. 7 Tahun 2015, statistik daerah provinsi bali tahun 2015, statistik daerah provinsi bali tahun 2016. Penelitian ini menggunakan teknik deskriptif komparatif. Adapun rasio yang digunakan yaitu : 


\section{Rasio Kemandirian Keuangan Daerah.}

Halim dan Kusufi (2012:221-234), rasio kemandirian keuangan daerah menggambarkan upaya aparat SKPD dalam mendanai program pemerintahannya dan seluruh program pemerintah yang dilakukan dengan tujuan untuk menyejahterakan masyarakatnya. Rasio kemandirian dihitung dengan membandingkan total PAD dengan total pendapatan eksternal daerah. Kriteria penilaian tingkat kemandirian keuangan daerah yaitu :

\section{Tabel 1.}

Kriteria Penilaian Kemandirian Keuangan Daerah

\begin{tabular}{ccc}
\hline Kemampuan Daerah & $\begin{array}{c}\text { Persentase Kinerja } \\
\text { Keuangan }(\%)\end{array}$ & Pola Hubungan \\
\hline Rendah Sekali & $0,00-25,00$ & Intruktif \\
Rendah & $25,01-50,00$ & Konsultatif \\
Sedang & $50,01-75,00$ & Partisipatif \\
Tinggi & $75,01-100,00$ & Delegatif \\
\hline
\end{tabular}

Sumber: Halim (2008:232)

\section{Rasio DDF}

Mahmudi (2010:143) mengungkapkan bahwa rasio DDF menunjukkan kemampuan aparat pemerintah daerah dalam memaksimalkan dan juga mengelola potensi PAD yang ada di daerahnya. DDF dihitung dengan membandingkan total PAD dengan total pendapatan daerah Adapun kriteria penilaian DDF adalah sebagai berikut :

Tabel 2.

Kriteria Penilaian DDF

\begin{tabular}{cc}
\hline Persentase Kinerja Keuangan (\%) & Kriteria \\
\hline $0,00-10,00$ & Sangat Kurang \\
$10,01-20,00$ & Kurang \\
$20,01-30,00$ & Sedang \\
$30,01-40,00$ & Cukup \\
$40,01-50,00$ & Baik \\
$>50,01$ & Sangat Baik \\
\hline
\end{tabular}

Sumber : Tim Litbang Depdagri-Fisipol UGM,1991 


\section{Rasio Efektivitas PAD}

Dalam Halim (2008:234), rasio efektivitas PAD menjelaskan kinerja pdalam merealisasikan jumlah PAD dari jumlah PAD yang telah ditargetkan. Rasio efektivitas PAD dihitung melalui perbandingan antara total realisasi PAD dengan total anggaran PAD. Kriteria penilaian efektivitas PAD adalah sebagai berikut:

Tabel 3.

\section{Kriteria Penilaian Efektivitas PAD}

\begin{tabular}{cc}
\hline Persentase Kinerja Keuangan (\%) & Kriteria \\
\hline$>100$ & Sangat Efektif \\
100 & Efektif \\
$90-99$ & Cukup Efektif \\
$75-89$ & Kurang Efektif \\
$<75$ & Tidak Efektif \\
\hline Sumber: Mahsun (2006:187) &
\end{tabular}

\section{Rasio Pertumbuhan PAD}

Dalam Mahmudi (2010:138), rasio pertumbuhan (growth ratio) menunjukkan kemampuan apparat pemerintah daerah dalam merealisasikan PAD selama beberapa tahun anggaran. Kriteria penilaian terhadap rasio pertumbuhan PAD adalah realisasi PAD pemerintah daerah meningkat dari tahun sebelumnya maka pertumbuhan PAD dapat dikatakan positif dan sebaliknya.

\section{Rasio Keserasian Belanja}

Menurut Halim dan Kusufi (2012:236), rasio keserasian belanja menunjukkan kemampuan aparat pemerintah daerah dalam menyusun skala prioritas dalam mengalokasikan belanja pembangunan dan belanja rutin secara optimal. Untuk menghitung nilai keserasian belanja dapat dilakukan dengan melakukan analisis dari sisi belanja modal dengan belanja operasional. Kriteria penilaian terhadap rasio keserasian belanja yaitu apabila kinerja keuangan 
pemerintah dikatakan baik apabila belanja yang dikeluarkan oleh pemerintah adalah belanja modal.

\section{Rasio Efisiensi Belanja}

Menurut Halim (2014:112), rasio efisiensi belanja merupakan rasio yang menunjukkan kemampuan pemerintah dalam mengelola belanja daerahnya agar tidak melebihi anggaran. Pengukuran terhadap efisiensi belanja dilakukan dengan membandingkan besarnya jumlah belanja yang telah dianggarkan oleh pemerintah sebelumnya dengan jumlah realisasi belanja yang telah dianggarkan oleh pemerintah sebelumnya. Kriteria penilaian efisiensi belanja yaitu :

\section{Tabel 1.}

Kriteria Penilaian Efisiensi Belanja

\begin{tabular}{cc}
\hline Persentase Kinerja Keuangan (\%) & Kriteria \\
\hline$>100$ & Tidak efsien \\
$=100$ & Efisien berimbang \\
$<100$ & Efisien \\
\hline
\end{tabular}

Sumber: Mahsun (2012:187)

\section{HASIL DAN PEMBAHASAN}

\section{Hasil Uji Normalitas}

Uji normalitas yang telah dilakukan menunjukkan hasil bahwa $\mathrm{H}_{0}$ diterima dan data yang diuji telah berdistribusi normal dikarenakan nilai Asymp.Sig (2tailed) yang lebih besar dari tingkat $\alpha$ yang digunakan. 
Tabel 2

Hasil Uji Normalitas

One-Sample Kolmogorov-Smirnov Test

\begin{tabular}{llr}
\hline & & $\begin{array}{c}\text { Unstandardized } \\
\text { Residual }\end{array}$ \\
\hline $\mathrm{N}$ & Mean & 25 \\
Normal Parameters & a,b & .0000000 \\
& Std. Deviation & 33.24035182 \\
Most Extreme Differences & Absolute & .104 \\
& Positive & .104 \\
& Negative & -.077 \\
Test Statistic & & .104 \\
Asymp. Sig. (2-tailed) & & $.200^{\mathrm{c}, \mathrm{d}}$ \\
\hline
\end{tabular}

a. Test distribution is Normal.

b. Calculated from data.

c. Lilliefors Significance Correction.

d. This is a lower bound of the true significance.

Sumber : Data diolah, 2017

\section{Kinerja Keuangan Daerah Kota Denpasar Dengan Provinsi Bali}

Tabel berikut ini menyajikan hasil perhitungan rasio-rasio keuangan pada pengukuran kinerja keuangan di kota Denpasar dan provinsi Bali selama tahun 2011 hingga tahun 2015.

Tabel 3.

Hasil Perhitungan Rasio Keuangan Pada Kinerja Keuangan Daerah Kota Denpasar Tahun 2011-2015

\begin{tabular}{|c|c|c|c|c|c|c|c|}
\hline \multirow{2}{*}{ Tahun } & \multirow{2}{*}{$\begin{array}{c}\text { Rasio } \\
\text { Kemandirian } \\
\text { Keuangan } \\
\text { Daerah (\%) }\end{array}$} & \multirow{2}{*}{$\begin{array}{c}\text { Rasio } \\
\text { DDF } \\
(\%)\end{array}$} & \multirow{2}{*}{$\begin{array}{c}\text { Rasio } \\
\text { Efektivitas } \\
\text { PAD }(\%)\end{array}$} & \multirow{2}{*}{$\begin{array}{c}\text { Rasio } \\
\text { Pertumbuhan } \\
\text { PAD }(\%)\end{array}$} & \multicolumn{2}{|c|}{$\begin{array}{c}\text { Rasio Keserasian } \\
\text { Belanja }(\%)\end{array}$} & \multirow{2}{*}{$\begin{array}{c}\text { Rasio } \\
\text { Efisiensi } \\
\text { Belanja } \\
(\%)\end{array}$} \\
\hline & & & & & $\begin{array}{c}\text { Rasio } \\
\text { Belanja } \\
\text { Modal } \\
(\%)\end{array}$ & $\begin{array}{c}\text { Rasio } \\
\text { Belanja } \\
\text { Operasional } \\
(\%)\end{array}$ & \\
\hline 2011 & 59 & 37 & 183 & 65 & 8 & 92 & 107 \\
\hline 2012 & 59 & 37 & 145 & 20 & 16 & 84 & 107 \\
\hline 2013 & 74 & 43 & 128 & 29 & 17 & 83 & 114 \\
\hline 2014 & 68 & 40 & 114 & 6 & 14 & 86 & 106 \\
\hline 2015 & 77 & 43 & 114 & 11 & 11 & 89 & 100 \\
\hline
\end{tabular}


Tabel 4.

Perhitungan Rasio-Rasio Keuangan Pada Kinerja Keuangan Daerah Provinsi Bali Tahun 2011-2015

\begin{tabular}{|c|c|c|c|c|c|c|c|}
\hline \multirow{2}{*}{ Tahun } & \multirow{2}{*}{$\begin{array}{c}\text { Rasio } \\
\text { Kemandirian } \\
\text { Keuangan } \\
\text { Daerah (\%) }\end{array}$} & \multirow{2}{*}{$\begin{array}{c}\text { Rasio } \\
\text { DDF } \\
(\%)\end{array}$} & \multirow{2}{*}{$\begin{array}{c}\text { Rasio } \\
\text { Efektivitas } \\
\text { PAD }(\%)\end{array}$} & \multirow{2}{*}{$\begin{array}{c}\text { Rasio } \\
\text { Pertumbuhan } \\
\text { PAD }(\%)\end{array}$} & \multicolumn{2}{|c|}{$\begin{array}{l}\text { Rasio Keserasian } \\
\text { Belanja }(\%)\end{array}$} & \multirow{2}{*}{$\begin{array}{c}\text { Rasio } \\
\text { Efisiensi } \\
\text { Belanja } \\
(\%)\end{array}$} \\
\hline & & & & & $\begin{array}{c}\text { Rasio } \\
\text { Belanja } \\
\text { Modal } \\
(\%)\end{array}$ & $\begin{array}{c}\text { Rasio } \\
\text { Belanja } \\
\text { Operasional } \\
(\%)\end{array}$ & \\
\hline 2011 & 184 & 65 & 117 & 24 & 9 & 91 & 85 \\
\hline 2012 & 128 & 56 & 110 & 18 & 10 & 90 & 87 \\
\hline 2013 & 160 & 62 & 124 & 24 & 12 & 88 & 85 \\
\hline 2014 & 176 & 64 & 112 & 15 & 8 & 92 & 89 \\
\hline 2015 & 158 & 61 & 102 & 4 & 11 & 89 & 90 \\
\hline
\end{tabular}

Sumber: Statistik Daerah Provinsi Bali Tahun 2015 dan 2016 (data diolah)

Tabel 5.

Ringkasan Hasil Uji Mann-Whitney Rasio-Rasio Keuangan Pada Kinerja Keuangan Daerah Kota Denpasar Dengan Provinsi Bali

\begin{tabular}{|c|c|c|c|c|}
\hline Rasio & $\begin{array}{c}\text { Exact Sig. } \\
{[2 *(1-\text { tailed }} \\
\text { Sig. })]\end{array}$ & $\begin{array}{c}\text { Tingkat } \\
\alpha\end{array}$ & Hasil Uji & $\begin{array}{l}\text { Wilayah Dengan } \\
\text { Kinerja yang Tinggi }\end{array}$ \\
\hline $\begin{array}{l}\text { Kemandirian } \\
\text { Keuangan } \\
\text { Daerah }\end{array}$ & 0,008 & 0,05 & Berbeda nyata & Bali \\
\hline DDF & 0,008 & 0,05 & Berbeda nyata & Bali \\
\hline Efektivitas PAD & 0,095 & 0,05 & Tidak berbeda nyata & Denpasar \\
\hline $\begin{array}{l}\text { Pertumbuhan } \\
\text { PAD }\end{array}$ & 0,690 & 0,05 & Tidak berbeda nyata & Denpasar \\
\hline $\begin{array}{l}\text { Belanja } \\
\text { Operasional }\end{array}$ & 0,310 & 0,05 & Tidak berbeda nyata & Denpasar \\
\hline Belanja Modal & 0,310 & 0,05 & Tidak berbeda nyata & Denpasar \\
\hline Efisiensi Belanja & 0,008 & 0,05 & Berbeda nyata & Bali \\
\hline
\end{tabular}

Selama tahun 2011 hingga tahun 2015 nilai rata-rata rasio kemandirian keuangan daerah kota Denpasar yaitu 67 persen dan dan berada dalam kategori yang sedang dengan pola hubungan partisipatif. sementara, provinsi Bali sebesar 161 persen. Dengan pola hubungan delegatif. Nilai rata-rata rasio DDF kota Denpasar selama tahun 2011 hingga tahun 2015 hanya sebesar 40 persen. Nilai 
tersebut berada dalam kategori cukup sementara, nilai rata-rata rasio DDF provinsi Bali adalah 62 persen dan berada dalam kategori sangat baik.

Nilai rata-rata rasio efektivitas PAD kota Denpasar dan provinsi Bali secara berturut-turut yaitu : 137 persen dan 113 persen. Kedua daerah tersebut berada dalam kategori sangat efektif. Tingkat pertumbuhan PAD di kota Denpasar selama tahun 2011 hingga tahun 2015 adalah sebesar 26 persen sementara, provinsi Bali hanya sebesar 17 persen. Nilai rata-rata belanja operasional yang dikeluarkan oleh pemerintah kota Denpasar sebesar 87 persen sementara, pemerintah provinsi Bali sebesar 90 persen.

Semakin kecil persentase rasio belanja operasional maka, semakin baik kinerja keuangan pemerintah tersebut. Nilai rata-rata persentase belanja modal kota Denpasar sebesar 13 persen provinsi Bali sebesar 10 persen. Semakin tinggi tingkat persentase belanja modal maka, semakin baik kinerja pemerintah tersebut.

Nilai rata-rata persentase rasio efisiensi belanja yang dikeluarkan oleh pemerintah kota Denpasar selama tahun 2011 hingga tahun 2015 adalah 107 persen dan berada dalam kategori tidak efisien sementara, nilai rata-rata rasio efisiensi belanja yang dikeluarkan oleh pemerintah provinsi Bali dalam periode yang sama yaitu : 87 persen dan berada dalam kategori efisien.

\section{Kinerja Keuangan Daerah Kabupaten Badung Dengan Provinsi Bali}

Tabel berikut ini menyajikan hasil perhitungan rasio-rasio keuangan pada pengukuran kinerja keuangan di kabupaten Badung dan provinsi Bali selama tahun 2011 hingga tahun 2015. 
Tabel 6.

Perhitungan Rasio-Rasio Keuangan Pada Kinerja Keuangan Daerah Kabupaten Badung Tahun 2011-2015

\begin{tabular}{|c|c|c|c|c|c|c|c|}
\hline \multirow{2}{*}{ Tahun } & \multirow{2}{*}{$\begin{array}{c}\text { Rasio } \\
\text { Kemandirian } \\
\text { Keuangan } \\
\text { Daerah (\%) }\end{array}$} & \multirow{2}{*}{$\begin{array}{c}\text { Rasio } \\
\text { DDF } \\
(\%)\end{array}$} & \multirow{2}{*}{$\begin{array}{c}\text { Rasio } \\
\text { Efektivitas } \\
\text { PAD }(\%)\end{array}$} & \multirow{2}{*}{$\begin{array}{c}\text { Rasio } \\
\text { Pertumbuhan } \\
\text { PAD }(\%)\end{array}$} & \multicolumn{2}{|c|}{$\begin{array}{c}\text { Rasio Keserasian } \\
\text { Belanja }(\%)\end{array}$} & \multirow{2}{*}{$\begin{array}{c}\text { Rasio } \\
\text { Efisiensi } \\
\text { Belanja } \\
(\%)\end{array}$} \\
\hline & & & & & $\begin{array}{c}\text { Rasio } \\
\text { Belanja } \\
\text { Modal } \\
(\%)\end{array}$ & $\begin{array}{c}\text { Rasio } \\
\text { Belanja } \\
\text { Operasional } \\
(\%)\end{array}$ & \\
\hline 2011 & 316 & 76 & 152 & 44 & 13 & 87 & 105 \\
\hline 2012 & 250 & 71 & 142 & 33 & 27 & 73 & 114 \\
\hline 2013 & 337 & 77 & 122 & 22 & 28 & 72 & 96 \\
\hline 2014 & 369 & 79 & 124 & 19 & 29 & 71 & 100 \\
\hline 2015 & 409 & 80 & 116 & 10 & 27 & 73 & 98 \\
\hline
\end{tabular}

Sumber : Statistik Keuangan Daerah Kabupaten/Kota Se-Bali Tahun 2011-2015, (data diolah)

Tabel 7.

Perhitungan Rasio-Rasio Keuangan Pada Kinerja Keuangan Daerah Provinsi Bali Tahun 2011-2015

\begin{tabular}{|c|c|c|c|c|c|c|c|}
\hline \multirow{2}{*}{ Tahun } & \multirow{2}{*}{$\begin{array}{c}\text { Rasio } \\
\text { Kemandirian } \\
\text { Keuangan } \\
\text { Daerah (\%) }\end{array}$} & \multirow{2}{*}{$\begin{array}{c}\text { Rasio } \\
\text { DDF } \\
(\%)\end{array}$} & \multirow{2}{*}{$\begin{array}{c}\text { Rasio } \\
\text { Efektivitas } \\
\text { PAD }(\%)\end{array}$} & \multirow{2}{*}{$\begin{array}{c}\text { Rasio } \\
\text { Pertumbuhan } \\
\text { PAD }(\%)\end{array}$} & \multicolumn{2}{|c|}{$\begin{array}{c}\text { Rasio Keserasian } \\
\text { Belanja }(\%)\end{array}$} & \multirow{2}{*}{$\begin{array}{c}\text { Rasio } \\
\text { Efisiensi } \\
\text { Belanja } \\
(\%)\end{array}$} \\
\hline & & & & & $\begin{array}{c}\text { Rasio } \\
\text { Belanja } \\
\text { Modal } \\
(\%)\end{array}$ & $\begin{array}{c}\text { Rasio } \\
\text { Belanja } \\
\text { Operasional } \\
(\%)\end{array}$ & \\
\hline 2011 & 184 & 65 & 117 & 24 & 9 & 91 & 85 \\
\hline 2012 & 128 & 56 & 110 & 18 & 10 & 90 & 87 \\
\hline 2013 & 160 & 62 & 124 & 24 & 12 & 88 & 85 \\
\hline 2014 & 176 & 64 & 112 & 15 & 8 & 92 & 89 \\
\hline 2015 & 158 & 61 & 102 & 4 & 11 & 89 & 90 \\
\hline
\end{tabular}

Sumber : Statistik Daerah Provinsi Bali Tahun 2015 dan 2016, (data diolah)

Tabel 8.

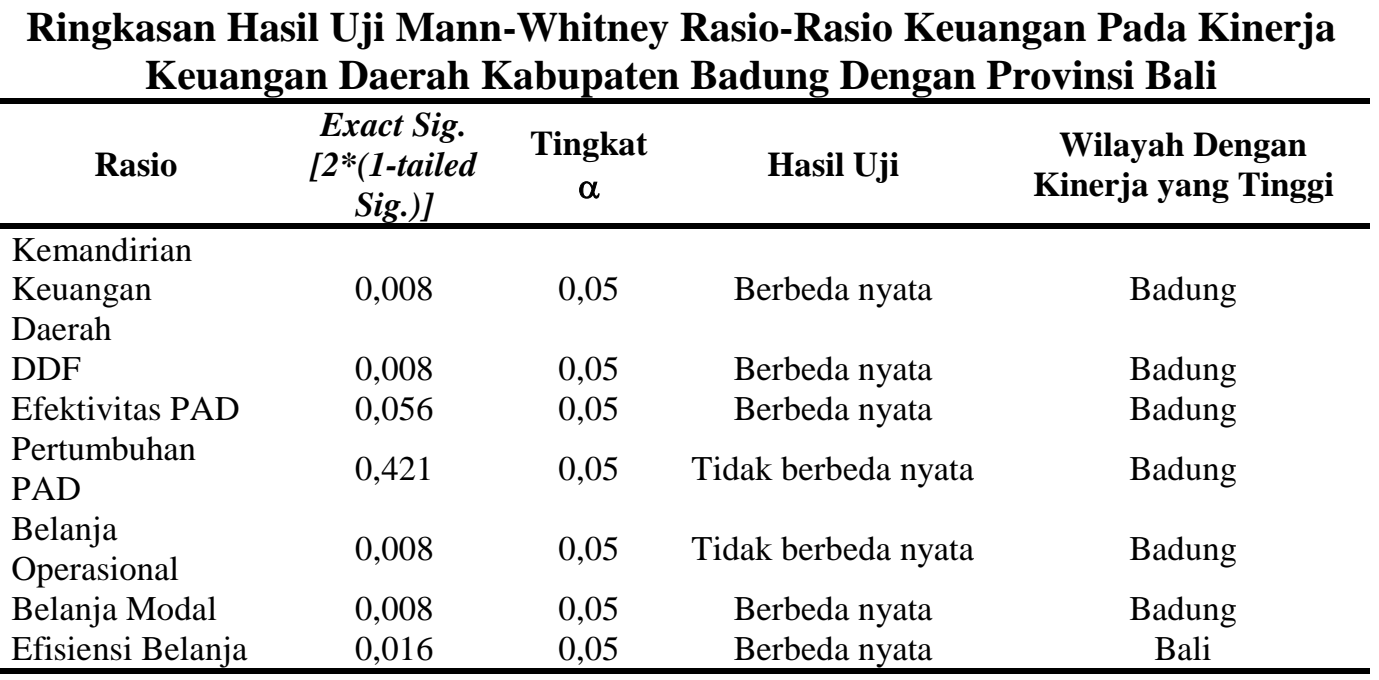

Sumber : Data diolah 
Tingkat rasio kemandirian keuangan daerah kabupaten Badung selama tahun 2011 hingga tahun 2015 sebesar 336 persen nilainya lebih tinggi dibandingkan dengan nilai provinsi Bali sebesar 161 persen. Nilai rata-rata rasio DDF kabupaten Badung adalah sebesar 77 persen sementara, nilai rata-rata provinsi Bali yaitu sebesar 62 persen. Nilao rata-rata rasio efektivitas PAD kabupaten Badung dan provinsi Bali selama tahun 2011 hingga tahun 2015 adalah sebesar 131 persen dan 113 persen. Kedua wilayah tersebut berada dalam kategori sangat efektif.

Selama tahun 2011 hingga tahun 2015, rata-rata kabupaten Badung mengalami peningkatan pertumbuhan PAD sebanyak 26 persen sementara provinsi Bali hanya sebesar 17 persen. Nilai rata-rata rasio belanja operasional kabupaten Badung adalah sebesar 75 persen sementara, nilai rata-rata rasio belanja operasional provinsi Bali adalah sebesar 90 persen. Nilai rata-rata rasio belanja modal kabupaten Badung adalah sebesar 25 persen sementara nilai ratarata rasio belanja modal provinsi Bali adalah sebesar 10 persen Dari sisi efisiensi belanja nilai rata-rata efisiensi belanja provinsi Bali adalah 87 persen dan berada dalam kategori efisien sementara kabupaten Badung adalah 107 persen dan berada dalam kategori tidak efisien.

\section{Kinerja Keuangan Daerah Kabupaten Gianyar Dengan Provinsi Bali}

Tabel berikut menyajikan rasio kinerja keuangan daerah kabupaten Gianyar dan provinsi Bali selama tahun 2011 hingga tahun 2015. 
Tabel 9.

\section{Perhitungan Rasio-Rasio Keuangan Pada Kinerja Keuangan Daerah} Kabupaten Gianyar Tahun 2011-2015

\begin{tabular}{|c|c|c|c|c|c|c|c|}
\hline \multirow{2}{*}{ Tahun } & \multirow{2}{*}{$\begin{array}{c}\text { Rasio } \\
\text { Kemandirian } \\
\text { Keuangan } \\
\text { Daerah (\%) }\end{array}$} & \multirow{2}{*}{$\begin{array}{c}\text { Rasio } \\
\text { DDF } \\
(\%)\end{array}$} & \multirow{2}{*}{$\begin{array}{c}\text { Rasio } \\
\text { Efektivitas } \\
\text { PAD }(\%)\end{array}$} & \multirow{2}{*}{$\begin{array}{c}\text { Rasio } \\
\text { Pertumbuhan } \\
\text { PAD }(\%)\end{array}$} & \multicolumn{2}{|c|}{$\begin{array}{c}\text { Rasio Keserasian } \\
\text { Belanja }(\%)\end{array}$} & \multirow{2}{*}{$\begin{array}{c}\text { Rasio } \\
\text { Efisiensi } \\
\text { Belanja } \\
(\%)\end{array}$} \\
\hline & & & & & $\begin{array}{c}\text { Rasio } \\
\text { Belanja } \\
\text { Modal } \\
(\%) \\
\end{array}$ & $\begin{array}{c}\text { Rasio } \\
\text { Belanja } \\
\text { Operasional } \\
(\%) \\
\end{array}$ & \\
\hline 2011 & 27 & 21 & 117 & 14 & 14 & 86 & 105 \\
\hline 2012 & 32 & 24 & 124 & 49 & 12 & 88 & 100 \\
\hline 2013 & 34 & 26 & 134 & 22 & 16 & 84 & 103 \\
\hline 2014 & 43 & 30 & 136 & 33 & 15 & 85 & 105 \\
\hline 2015 & 43 & 30 & 123 & 8 & 15 & 85 & 104 \\
\hline \multicolumn{8}{|c|}{ Sumber : Statistik Keuangan Daerah Kabupaten/Kota Se-Bali Tahun 2011-2015, (data diolah) } \\
\hline \multicolumn{8}{|c|}{$\begin{array}{c}\text { Tabel } 10 . \\
\text { Perhitungan Rasio-Rasio Keuangan Pada Kinerja Keuangan Daerah } \\
\text { Provinsi Bali Tahun 2011-2015 }\end{array}$} \\
\hline \multirow{2}{*}{ Tahun } & \multirow{2}{*}{$\begin{array}{l}\text { Rasio } \\
\text { Kemandirian } \\
\text { Keuangan } \\
\text { Daerah }(\%)\end{array}$} & \multirow{2}{*}{$\begin{array}{l}\text { Rasio } \\
\text { DDF } \\
(\%)\end{array}$} & \multirow{2}{*}{$\begin{array}{l}\text { Rasio } \\
\text { Efektivitas } \\
\text { PAD }(\%)\end{array}$} & \multirow{2}{*}{$\begin{array}{l}\text { Rasio } \\
\text { Pertumbuhan } \\
\text { PAD }(\%)\end{array}$} & \multicolumn{2}{|c|}{$\begin{array}{l}\text { Rasio Keserasian } \\
\text { Belanja }(\%)\end{array}$} & \multirow{2}{*}{$\begin{array}{l}\text { Rasio } \\
\text { Efisiensi } \\
\text { Belanja } \\
\quad(\%)\end{array}$} \\
\hline & & & & & $\begin{array}{c}\text { Rasio } \\
\text { Belanja } \\
\text { Modal } \\
(\%)\end{array}$ & $\begin{array}{c}\text { Rasio } \\
\text { Belanja } \\
\text { Operasional } \\
(\%)\end{array}$ & \\
\hline 2011 & 184 & 65 & 117 & 24 & 9 & 91 & 85 \\
\hline 2012 & 128 & 56 & 110 & 18 & 10 & 90 & 87 \\
\hline 2013 & 160 & 62 & 124 & 24 & 12 & 88 & 85 \\
\hline 2014 & 176 & 64 & 112 & 15 & 8 & 92 & 89 \\
\hline 2015 & 158 & 61 & 102 & 4 & 11 & 89 & 90 \\
\hline
\end{tabular}

Sumber : Statistik Daerah Provinsi Bali Tahun 2015 dan 2016 (data diolah)

Tabel 11.

Ringkasan Hasil Uji Mann-Whitney Rasio-Rasio Keuangan Pada Kinerja Keuangan Daerah Kabupaten Gianyar Dengan Provinsi Bali

\begin{tabular}{|c|c|c|c|c|}
\hline Rasio & $\begin{array}{c}\text { Exact Sig. } \\
{[2 *(1-t a i l e d} \\
\text { Sig. })]\end{array}$ & Tingkat $\alpha$ & Hasil Uji & $\begin{array}{l}\text { Wilayah Dengan } \\
\text { Kinerja yang Tinggi }\end{array}$ \\
\hline $\begin{array}{l}\text { Kemandirian } \\
\text { Keuangan } \\
\text { Daerah }\end{array}$ & 0,008 & 0,05 & Berbeda nyata & Bali \\
\hline DDF & 0,008 & 0,05 & Berbeda nyata & Bali \\
\hline Efektivitas PAD & 0,056 & 0,05 & Tidak berbeda nyata & Gianyar \\
\hline $\begin{array}{l}\text { Pertumbuhan } \\
\text { PAD }\end{array}$ & 0,690 & 0,05 & Tidak berbeda nyata & Gianyar \\
\hline $\begin{array}{l}\text { Belanja } \\
\text { Operasional }\end{array}$ & 0,008 & 0,05 & Berbeda nyata & Gianyar \\
\hline Belanja Modal & 0,008 & 0,05 & Berbeda nyata & Gianyar \\
\hline Efisiensi Belanja & 0,008 & 0,05 & Berbeda nyata & Bali \\
\hline
\end{tabular}

Sumber : Data diolah 
Nilai rata-rata kemandirian keuangan pemerintah kabupaten Gianyar, selama tahun 2011 hingga tahun 2015 adalah sebesar 36 persen. Nilai tersebut berada dalam kategori kemampuan daerah yang rendah dengan pola hubungan yang konsultatif sementara, provinsi Bali sebesar 161 persen dan berada dalam kemampuan keuangan daerah yang tinggi dengan pola hubungan kemandirian keuangan daerah yang delegatif. Nilai rata-rata rasio DDF kabupaten Gianyar adalah sebesar 26 persen dan nilai tersebut berada dalam kriteria DDF yang sedang.

Nilai rata-rata rasio DDF provinsi Bali selama tahun 2011 hingga tahun 2015 yaitu sebesar 62 persen dan nilai tersebut berada dalam kriteria sangat baik. Nilai rasio efektivitas PAD kabupaten Gianyar sebesar 127 persen. Nilai tersebut berada dalam kategori lebih dari 100 persen dan berada dalam kriteria sangat efektif, sementara provinsi Bali sebesar 113 persen. Nilai tersebut berada dalam kategori efektif. Nilai rata-rata rasio pertumbuhan PAD kabupaten Gianyar yaitu 25 persen sementara, provinsi Bali yaitu hanya 17 persen.

Nilai rata-rata rasio belanja operasional provinsi Bali sebesar 90 persen, sementara nilai rata-rata rasio belanja operasional kabupaten Gianyar sebesar 86 persen. Nilai rata-rata rasio belanja modal kabupaten Gianyar adalah sebesar 14 persen dan provinsi Bali sebesar 10 persen. Kabupaten Gianyar memiliki nilai rata-rata rasio efisiensi belanja selama tahun 2011 hingga tahun 2015 adalah sebesar 103 persen dan nilai tersebut berada dalam kategori tidak efisien. Nilai rata-rata rasio efisiensi belanja provinsi Bali sebesar 87 persen dan berada dalam kriteria efisien. 


\section{Kinerja Keuangan Daerah Kabupaten Tabanan Dengan Provinsi Bali}

Tabel berikut ini menyajikan hasil perhitungan rasio kinerja keuangan kabupaten Tabanan dan provinsi Bali selama tahun 2011 hingga tahun 2015.

Tabel 12.

Perhitungan Rasio-Rasio Keuangan Pada Kinerja Keuangan Daerah Kabupaten Tabanan Tahun 2011-2015

\begin{tabular}{|c|c|c|c|c|c|c|c|}
\hline \multirow{2}{*}{ Tahun } & \multirow{2}{*}{$\begin{array}{c}\text { Rasio } \\
\text { Kemandirian } \\
\text { Keuangan } \\
\text { Daerah (\%) }\end{array}$} & \multirow{2}{*}{$\begin{array}{c}\text { Rasio } \\
\text { DDF } \\
(\%)\end{array}$} & \multirow{2}{*}{$\begin{array}{c}\text { Rasio } \\
\text { Efektivitas } \\
\text { PAD (\%) }\end{array}$} & \multirow{2}{*}{$\begin{array}{c}\text { Rasio } \\
\text { Pertumbuhan } \\
\text { PAD }(\%)\end{array}$} & \multicolumn{2}{|c|}{$\begin{array}{c}\text { Rasio Keserasian } \\
\text { Belanja }(\%)\end{array}$} & \multirow{2}{*}{$\begin{array}{c}\text { Rasio } \\
\text { Efisiensi } \\
\text { Belanja } \\
(\%)\end{array}$} \\
\hline & & & & & $\begin{array}{c}\text { Rasio } \\
\text { Belanja } \\
\text { Modal } \\
(\%)\end{array}$ & $\begin{array}{c}\text { Rasio } \\
\text { Belanja } \\
\text { Operasional } \\
(\%)\end{array}$ & \\
\hline 2011 & 19 & 16 & 128 & 31 & 8 & 92 & 108 \\
\hline 2012 & 21 & 17 & 134 & 30 & 13 & 87 & 107 \\
\hline 2013 & 26 & 20 & 140 & 39 & 11 & 89 & 105 \\
\hline 2014 & 25 & 20 & 128 & 7 & 10 & 90 & 104 \\
\hline 2015 & 23 & 19 & 123 & 10 & 7 & 93 & 111 \\
\hline \multicolumn{8}{|c|}{ Sumber : Statistik Keuangan Daerah Kabupaten/Kota Se-Bali Tahun 2011-2015, (data diolah) } \\
\hline \multicolumn{8}{|c|}{$\begin{array}{c}\text { Tabel } 13 . \\
\text { Perhitungan Rasio-Rasio Keuangan Pada Kinerja Keuangan Daerah } \\
\text { Provinsi Bali Tahun 2011-2015 }\end{array}$} \\
\hline \multirow{2}{*}{ Tahun } & \multirow{2}{*}{$\begin{array}{l}\text { Rasio } \\
\text { Kemandirian } \\
\text { Keuangan } \\
\text { Daerah }(\%)\end{array}$} & \multirow{2}{*}{$\begin{array}{l}\text { Rasio } \\
\text { DDF } \\
(\%)\end{array}$} & \multirow{2}{*}{$\begin{array}{l}\text { Rasio } \\
\text { Efektivitas } \\
\text { PAD }(\%)\end{array}$} & \multirow{2}{*}{$\begin{array}{l}\text { Rasio } \\
\text { Pertumbuhan } \\
\text { PAD }(\%)\end{array}$} & \multicolumn{2}{|c|}{$\begin{array}{l}\text { Rasio Keserasian } \\
\text { Belanja }(\%)\end{array}$} & \multirow{2}{*}{$\begin{array}{l}\text { Rasio } \\
\text { Efisiensi } \\
\text { Belanja } \\
\quad(\%)\end{array}$} \\
\hline & & & & & $\begin{array}{c}\text { Rasio } \\
\text { Belanja } \\
\text { Modal } \\
(\%)\end{array}$ & $\begin{array}{c}\text { Rasio } \\
\text { Belanja } \\
\text { Operasional } \\
(\%)\end{array}$ & \\
\hline 2011 & 184 & 65 & 117 & 24 & 9 & 91 & 85 \\
\hline 2012 & 128 & 56 & 110 & 18 & 10 & 90 & 87 \\
\hline 2013 & 160 & 62 & 124 & 24 & 12 & 88 & 85 \\
\hline 2014 & 176 & 64 & 112 & 15 & 8 & 92 & 89 \\
\hline 2015 & 158 & 61 & 102 & 4 & 11 & 89 & 90 \\
\hline
\end{tabular}

Sumber : Statistik Daerah Provinsi Bali Tahun 2015 dan 2016, (data diolah) 
Tabel 14.

Ringkasan Hasil Uji Mann-Whitney Rasio-Rasio Keuangan Pada Kinerja Keuangan Daerah Kabupaten Tabanan Dengan Provinsi Bali

\begin{tabular}{lcccc}
\hline \multicolumn{1}{c}{ Rasio } & $\begin{array}{c}\text { Exact Sig. } \\
{[2 *(\mathbf{1} \text {-tailed }} \\
\text { Sig. })]\end{array}$ & $\begin{array}{c}\text { Tingkat } \\
\boldsymbol{\alpha}\end{array}$ & Hasil Uji & $\begin{array}{c}\text { Wilayah Dengan } \\
\text { Kinerja yang Tinggi }\end{array}$ \\
\hline $\begin{array}{l}\text { Kemandirian } \\
\text { Keuangan }\end{array}$ & 0,008 & 0,05 & Berbeda nyata & Bali \\
$\begin{array}{l}\text { Daerah } \\
\text { DDF }\end{array}$ & 0,008 & 0,05 & Berbeda nyata & Bali \\
Efektivitas PAD & 0,016 & 0,05 & Tidak Berbeda nyata & Tabanan \\
$\begin{array}{l}\text { Pertumbuhan } \\
\text { PAD }\end{array}$ & 0,421 & 0,05 & Tidak berbeda nyata & Tabanan \\
$\begin{array}{l}\text { Belanja } \\
\text { Operasional }\end{array}$ & 0,841 & 0,05 & Tidak berbeda nyata & Tabanan dan Bali \\
$\begin{array}{l}\text { Belanja Modal } \\
\text { Efisiensi Belanja }\end{array}$ & 0,841 & 0,05 & Tidak berbeda nyata & Tabanan dan Bali \\
Sumber : Data diolah & 0,008 & 0,05 & Berbeda nyata & Bali \\
\hline
\end{tabular}

Nilai rata-rata rasio kemandirian keuangan daerah kkabupaten Tabanan, selama tahun 2011 hingga tahun 2015 adalah sebesar 23 persen. Nilai tersebut berada dalam kategori kemampuan daerah yang rendah dengan pola hubungan yang konsultatif. Nilai rata-rata rasio kemandirian keuangan daerah provinsi Bali selama tahun 2011 hingga tahun 2015 adalah 161 persen dan berada dalam kriteria kemampuan daerah yang tinggi dengan pola hubungan yang delegatif.

Nilai rasio DDF kabupaten Tabanan adalah sebesar 18 persen dan berada dalam kategori kurang sementara, nilai rata-rata rasio DDF provinsi Bali adalah sebesar 62 persen dan berada dalam kategori sangat baik,. Nilai rasio efektivitas PAD kabupaten Tabanan sebesar 131 persen dan nilai tersebut berada dalam kategori sangat efektif. Nilai rasio efektivitas PAD provinsi Bali adalah sebesar 113 persen dan nilai tersebut berada dalam kategori efektif. Nilai rata-rata pertumbuhan PAD kabupaten Tabanan selama tahun 2011 hingga tahun 2015 
yaitu sebesar 23 persen, sementara nilai rata-rata pertumbuhan PAD provinsi Bali yaitu sebesar 17 persen.

Nilai rata-rata rasio belanja operasional kabupaten Tabanan selama tahun 2011 hingga tahun 2015 adalah sebesar 90 persen nilai tersebut sama dengan nilai rasio belanja operasional provinsi Bali yang juga sebesar 90 persen. nilai rata-rata rasio belanja modal kabupaten Tabanan selama tahun 2011 hingga tahun 2015 adalah sebesar 10 persen sama dengan nilai rasio belanja operasional provinsi Bali yang juga sebesar 10 persen.

Nilai rata-rata rasio efisiensi belanja kabupaten Tabanan dalam peiode waktu yang sama adalah sebesar 107 persen dan berada dalam kategori tidak efisien sementara, nilai rata-rata rasio efisiensi belanja provinsi Bali selama tahun 2011 hingga tahun 2015 adalah sebesar 79 persen dan berada dalam kategori efisien.

\section{SIMPULAN}

\section{Kinerja Keuangan Daerah Kota Denpasar Dengan Provinsi Bali}

Dari sisi kemandirian keuangan daerah menunjukkan hasil yang berbeda nyata dan kinerja keuangan daerah kota Denpasar lebih rendah dibandingkan dengan kinerja keuangan pemerintah provinsi Bali. Dari sisi DDF, perbandingan kinerja keuangan daerah kota Denpasar dengan provinsi Bali juga berbeda nyata dan kinerja keuangan daerah kota Denpasar lebih rendah dibandingkan dengan provinsi Bali.

Dari sisi efektivitas PAD kota Denpasar dengan provinsi Bali menunjukkan hasil yang tidak berbeda nyata dan kinerja keuangan daerah kota Denpasar dari 
efektivitas PAD lebih unggul dibandingkan dengan provinsi Bali. Dari sisi pertumbuhan PAD kota Denpasar dengan provinsi Bali jika dibandingkan menunjukkan hasil yang tidak berbeda nyata dan kinerja keuangan daerah kota Denpasar lebih unggul dibandingkan dengan provinsi Bali.

Dari sisi keserasian belanja, pada sisi belanja operasional dan belanja modal menunjukkan hasil yang tidak berbeda nyata. Baik dari sisi belanja operasional maupun belanja modal kinerja keuangan daerah kota Denpasar lebih unggul provinsi Bali. Dari sisi efisiensi belanja, perbandingan kinerja keuangan kota Denpasar dengan provinsi Bali menunjukkan hasil yang berbeda nyata dan kinerja keuangan daerah kota Denpasar lebih rendah dibandingkan dengan provinsi Bali.

\section{Kinerja Keuangan Daerah Kabupaten Badung Dibandingkan Dengan Kinerja Keuangan Provinsi Bali}

Dari sisi kemandirian keuangan daerah, kinerja keuangan daerah kabupaten Badung dengan provinsi Bali menunjukkan hasil yang berbeda nyata dan kinerja keuangan daerah kabupaten Badung ebih unggul dibandingkan dengan provinsi Bali. Dari sisi DDF perbandingan kinerja keuangan daerah kabupaten Badung dengan provinsi Bali menunjukkan hasil uji yang berbeda nyata dan kinerja keuangan daerah kabupaten lebih unggul dibandingkan dengan provinsi Bali.

Dari sisi efektivitas PAD perbandingan kinerja keuangan daerah kabupaten Badung dengan provinsi Bali menunjukkan hasil uji yang tidak berbeda nyata dan kinerja keuangan daerah kabupaten lebih unggul dibandingkan dengan provinsi Bali. Dari sisi pertumbuhan PAD perbandingan kinerja keuangan daerah 
kabupaten Badung dengan provinsi Bali menunjukkan hasil uji yang tidak berbeda nyata dan kinerja keuangan daerah kabupaten Badung lebih unggul dibandingkan dengan provinsi Bali.

Dari sisi keserasian belanja, perbandingan kinerja keuangan daerah kabupaten Badung dengan provinsi Bali menunjukkan hasil uji yang berbeda nyata. Baik dari sisi belanja operasional dan belanja modal, kinerja keuangan daerah kabupaten Badung lebih unggul dibandingkan dengan provinsi Bali. Dari sisi efisiensi belanja daerah perbandingan kinerja keuangan daerah kabupaten Badung dengan provinsi Bali menunjukkan hasil uji yang berbeda nyata dan kinerja keuangan daerah kabupaten Badung dari lebih rendah dibandingkan dengan provinsi Bali.

\section{Kinerja Keuangan Daerah Kabupaten Gianyar Dibandingkan Dengan Kinerja Keuangan Provinsi Bali}

Dari sisi kemandirian keuangan daerah, kinerja keuangan daerah kabupaten Gianyar dengan provinsi Bali menunjukkan hasil yang berbeda nyata dan kinerja keuangan daerah kabupaten Gianyar lebih rendah dibandingkan dengan provinsi Bali. Dari sisi DDF perbandingan kinerja keuangan daerah kabupaten Gianyar dengan provinsi Bali daerah smenunjukkan hasil uji yang berbeda nyata dan kinerja keuangan daerah kabupaten Gianyar lebih rendah dibandingkan dengan provinsi Bali.

Dari sisi efektivitas PAD perbandingan kinerja keuangan daerah kabupaten Gianyar dengan provinsi Bali menunjukkan hasil uji yang tidak berbeda nyata dan 
kinerja keuangan daerah kabupaten Gianyar lebih unggul dibandingkan dengan provinsi Bali. Dari sisi pertumbuhan PAD perbandingan kinerja keuangan daerah kabupaten Gianyar dengan provinsi Bali daerah menunjukkan hasil uji yang tidak berbeda nyata dan kinerja keuangan daerah kabupaten Gianyar lebih unggul dibandingkan dengan provinsi Bali.

Dari sisi keserasian belanja, perbandingan kinerja keuangan daerah kabupaten Gianyar dengan provinsi Bali menunjukkan hasil uji yang berbeda nyata. Pada sisi rasio belanja operasional dan belanja modal, kinerja keuangan daerah kabupaten Gianyar lebih unggul dibandingkan dengan provinsi Bali. Dari sisi efisiensi belanja, perbandingan kinerja keuangan daerah kabupaten Gianyar dengan provinsi Bali menunjukkan hasil uji yang berbeda nyata dan kinerja keuangan daerah kabupaten Gianyar dari sisi efisiensi belanja lebih rendah dibandingkan dengan provinsi Bali.

\section{Kinerja Keuangan Daerah Kabupaten Tabanan Dibandingkan Dengan Kinerja Keuangan Provinsi Bali}

Dari sisi kemandirian keuangan daerah, kinerja keuangan daerah kabupaten Tabanan dengan provinsi Bali menunjukkan hasil yang berbeda nyata dan kinerja keuangan daerah kabupaten Tabanan lebih rendah dibandingkan dengan provinsi Bali. Dari sisi DDF perbandingan kinerja keuangan daerah kabupaten Tabanan dengan provinsi Bali menunjukkan hasil uji yang berbeda nyata dan kinerja keuangan daerah kabupaten Tabanan lebih rendah dibandingkan dengan provinsi Bali. 
Dari sisi efektivitas PAD perbandingan kinerja keuangan daerah kabupaten Tabanan dengan provinsi Bali menunjukkan hasil uji yang tidak berbeda nyata dan kinerja keuangan daerah kabupaten Tabanan dari sisi efektivitas PAD lebih tinggi dibandingkan dengan provinsi Bali. Dari sisi pertumbuhan PAD perbandingan kinerja keuangan daerah kabupaten Tabanan dengan provinsi Bali menunjukkan hasil uji yang tidak berbeda nyata dan kinerja keuangan daerah kabupaten Tabanan lebih unggul dibandingkan dengan provinsi Bali.

Dari sisi keserasian belanja, pada belanja operasional dan belanja modal perbandingan kinerja keuangan daerah kabupaten Tabanan dengan provinsi Bali menunjukkan hasil uji yang tidak berbeda nyata. Kinerja keuangan daerah kabupaten Tabanan dari sisi belanja operasional dan belanja modal sama dengan kinerja keuangan pemerintah provinsi Bali. Dari sisi efisiensi belanja, perbandingan kinerja keuangan daerah kabupaten Gianyar dengan provinsi Bali menunjukkan hasil uji yang berbeda nyata dan kinerja keuangan daerah kabupaten Tabanan dari sisi efisiensi belanja daerah lebih rendah dibandingkan dengan provinsi Bali.

\section{REFERENSI}

Adefeso, Hammed Adetola. 2016. Productive Government Expenditure and Economic Performance In Sub-Saharan Africa: an Empirical Investigation. Zagreb International Review of Economics and Business, 19 (2): 1-18.

Amuka, Joseph I., Miracle O Ezeoke., Fredrick O Asogawa. 2016. Government Spending Pattern and Macroeconomic Stability: A Vector Autoregressive Model. International Journal of Economics and Financial Issues, 6 (4): 1930-1936.

Aydın, Celil., Merter Akıncı., Ömer Yılmaz. 2016. The Analysis of Visible Hand of Government: The Threshold Effect of Government Spending on 
Economic Growth. International Journal of Trade, Economics and Finance, 7 (5): 170-179.

Badan Litbang Depdagri RI dan FISIPOL-UGM.1991.Pengukuran Kemampuan Keuangan Daerah Tingkat II Dalam Rangka Otonomi Daerah yang Nyata dan Bertanggung Jawab. Jakarta.

Badan Pusat Statistik. 2014. Statistik Keuangan Pemerintah Kabupaten/Kota SeProvinsi Bali Tahun 2010-2014. Denpasar: BPS Bali.

2015. Statistik Keuangan Pemerintah Kabupaten/Kota Se-Provinsi Bali Tahun 2011-2015. Denpasar: BPS Bali.

-----------. 2011. Tabanan Dalam Angka 2011. Denpasar: BPS Bali.

------------ 2012. Bali Dalam Angka 2012. Denpasar: BPS Bali.

------------ 2012. Badung Dalam Angka 2012. Denpasar: BPS Bali.

------------ 2012. Denpasar Dalam Angka 2015. Denpasar: BPS Bali.

---------- 2015. Gianyar Dalam Angka 2015. Denpasar: BPS Bali.

------------ . 2015. Statistik Daerah Provinsi Bali 2015. Denpasar: BPS Bali.

------------ 2016. Statistik Daerah Provinsi Bali 2016. Denpasar: BPS Bali.

Doh-Nani,Richard dan Dadson Awunyo-Vitor. 2012. The Causal Link Between Government Expenditure and Government Revenue in Ghana. Asian Economic and Financial Review, 2 (2): 382-388.

Egbetunde, Tajudeen dan Ismail O Fasanya. 2014. Public Expenditure and Economic Growth in Nigeria: Evidence From Auto-Regressive Distributed Lag Specification. Zagreb International Review of Economics and Business, 17 (2): 45-58.

Fasoranti, Mary Modupe. 2012. The Effect of Government Expenditure on Infrastructure on The Growth of The Nigerian Economy 1977-2009. International Journal of Economics and Financial Issues, 2 (4): 513-518.

Fitriani, Ni Luh Putu dan A.A.N.B. Dwirandra. 2014. Penilaian Kinerja Keuangan Daerah Kabupaten/Kota di Provinsi Bali Tahun 2007-2011. E-Jurnal Akuntansi Universitas Udayana, 8 (1): 211-227.

Frank, Adu dan Ackah Ishmaell. 2014. Revisiting Government Spending and Growth Analysis in Ghana: A Disaggregated Analysis From 1970 to 2010. Journal of Economics and International Finance, 6 (7): 134-143.

Halim, Abdul. 2008. Akuntansi Keuangan Daerah. Jakarta: Salemba Empat. - 2014. Manajemen Keuangan Sektor Publik. Jakarta: Salemba Empat.

Halim, Abdul dan Muhammad Syam Kusufi. 2012. Akuntansi Keuangan Daerah.. Jakarta: Salemba Empat. 
Kayode, Ayinde., John Kuranga., Adewale F Lukman. 2015. Modeling Nigerian Government Expenditure, Revenue and Economic Growth: Co-Integration, Error Correction Mechanism and Combined Estimators Analysis Approach. Asian Economic and Financial Review, 5 (6): 858-867.

Martini, Kadek dan A.A.N.B Dwirandra. 2015. Pengaruh Kinerja Keuangan Daerah pada Alokasi Belanja Modal di Provinsi Bali. E-Jurnal Akuntansi Universitas Udayana, 10 (2): 426-443.

Mahmudi. 2010. Buku Seri Membudayakan Akuntabilitas Publik: Analisis Laporan Keuangan Pemerintah Daerah Panduan bagi Eksekutif, DPRD, dan Masyarakat dalam Pengambilan Keputusan Ekonomi, Sosial, dan Politik. Yogyakarta: UPP STIM YKPN.

2010. Manajemen Keuangan Daerah. Yogyakarta: Erlangga.

Mahsun, Mohamad., Firma Sulistyowati., Heribertus Andre Purwanugraha. 2007. Akuntansi Sektor Publik. Yogyakarta: BPFE

Mahsun, Mohamad. 2012. Perpajakan Edisi Revisi. Yogyakarta: ANDI.

Mokodompit, Paramitha Sandy., Sifrid S Pangemanan., Inggriani Elim. 2014. Analisis Kinerja Keuangan Pemerintah Daerah Kota Kotamobagu. Jurnal Emba, 2(2): 1521-1527.

Mulistini, Putu Nenden dan I Ketut Yadnyana. 2013. Perbandingan Kinerja Keuangan Pemerintah Kabupaten/Kota Kawasan Metropolitan Sarbagita Tahun Anggaran 2007-2011. E-Jurnal Akuntansi Universitas Udayana, 3(1): 92-108.

Nurlis. 2016. The Factors Affecting of the Capital Expenditure Allocation Case: The Local Government of Indonesia. Research Journal of Finance and Accounting, 7 (1): 107-113.

Nwosu,Damian C dan Harrison O Okafor. 2014. Government Revenue and Expenditure in Nigeria : A Disaggregated Analysis. Asian Economic and Financial Review, 4 (7): 877-892.

Oktavianus, Donny., Sri Murni., Ivonne S Saerang. 2015. Analisis Perbandingan Kemampuan Keuangan Daerah pada Kota Bitung dan Kota Tomohon Periode Anggaran 2010 - 2014, Jurnal EMBA, 3 (3): 927-938.

Patricia, Chude Nkiru dan Chude Daniel Izuchukwu. 2013. Impact of Government Expenditure on Economic Growth in Nigeria. International Journal of Business and Management Review, 1 (4): 64-71.

Pevcin, Primoz. 2012. Transfer Revenues, Expenditures and Tax Effort of Slovenian Municipalities. African Journal of Business Management, 6 (22): 6721-6728.

Peraturan Daerah Provinsi Bali Nomor 7 Tahun 2012 Tentang Perubahan Atas Peraturan Daerah Provinsi Bali Nomor 11 Tahun 2011 Tentang Anggaran 
Pendapatan dan Belanja Daerah Tahun Anggaran 2012.10 September 2012. Lembaran Daerah Provinsi Bali Tahun 2012 Nomor 7.

Nomor 7 Tahun 2013 Tentang Perubahan Atas Peraturan Daerah Provinsi Bali Nomor 11 Tahun 2012 Tentang Anggaran Pendapatan aan Belanja Daerah Tahun Anggaran 2013.25 Oktober 2013. Lembaran Daerah Provinsi Bali Tahun 2013 Nomor 7.

Nomor 7 Tahun 2014 Tentang Perubahan Atas Peraturan Daerah Provinsi Bali Nomor 10 Tahun 2013 Tentang Anggaran Pendapatan dan Belanja Daerah Tahun Anggaran 2014.1 Oktober 2014. Lembaran Daerah Provinsi Bali Tahun 2014 Nomor 7.

Nomor 8 Tahun 2011 Tentang Perubahan Atas Peraturan Daerah Provinsi Bali Nomor 6 Tahun 2010 Tentang Anggaran Pendapatan dan Belanja Daerah Tahun Anggaran 2011.31 Oktober 2011. Lembaran Daerah Provinsi Bali Tahun 2011 Nomor 8.

Nomor 7 Tahun 2015 Tentang Perubahan Atas Peraturan Daerah Provinsi Bali Nomor 9 Tahun 2014 Tentang Anggaran Pendapatan dan Belanja Daerah Tahun Anggaran 2015.25 September 2015. Lembaran Daerah Provinsi Bali Tahun 2015 Nomor 7.

Peraturan Menteri Dalam Negeri Nomor 13 Tahun 2006 Tentang Pedoman Pengelolan Keuangan Daerah. 15 Mei 2006.

Rahmawati, Ni Ketut Erna dan I Wayan Putra. 2016. Analisis Kinerja Keuangan Pemerintah Kabupaten Sumbawa Tahun Anggaran 2010-2012. E-Jurnal Akuntansi Universitas Udayana, 15 (3): 1767-1795.

Rosemary O Anazodo., Igbokwe-Ibeto., Chinyeaka Justine., NKOMAH Barisua Barry. 2016. Local Government Financial Autonomy: A Comparative Analysis of Nigeria and Brazil. Arabian Journal of Business and Management Review (OMAN Chapter), 5 (10): 38-54.

Saputra, Sandy Candra. Wayan Suwendra. Fridayana Yudiaatmaja. 2016. Analisis Kinerja Keuangan Pemerintah Daerah dalam Pengelolaan Anggaran Pendapatan dan Belanja Daerah di Kabupaten Jembrana Tahun 2010 2014. E-Journal Bisma Universitas Pendidikan Ganesha, 4.

Sijabat, Mentari Yosephen., Choirul Saleh., Abdul Wachid. 2014. Analisis Kinerja Keuangan serta Kemampuan Keuangan Pemerintah Daerah dalam Pelaksanaan Otonomi Daerah (Studi Pada Dinas Pendapatan Daerah dan Badan Pengelola Keuangan dan Aset Daerah Kota Malang Tahun Anggaran 2008-2012). Jurnal Administrasi Publik (JAP), 2 (2): 236-242.

Sumawan, I Wayan. dan I Made Sukartha. 2016. Faktor-Faktor yang Berpengaruh pada Kinerja Belanja Pemerintah Kabupaten/Kota di Provinsi Bali. EJurnal Akuntansi Universitas Udayana, 14 (3): 1727-1754. 
E-Jurnal Manajemen Unud, Vol. 7, No. 2, 2018: 1111-1141

Susilowati., Suharno dan Djoko Kristianto. 2016. Analisis Kinerja Keuangan Pemerintah Kabupaten Karanganyar Tahun Anggaran 2013 - 2015. Jurnal Akuntansi dan Sistem Teknologi Informasi, 12 (2): 229 - 237.

Udoka, Chris O dan Roland A Anyingang. 2015.The Effect of Public Expenditure on The Growth and Development of Nigerian Economy (1980-2012). International Review of Management and Business Research, 4 (3): 823834.

Venkataraman, Subramanya dan Arabi Urmi. 2017. Development Expenditure, Fiscal Consolidation and Public Revenue in India. International Journal of Accounting and Economic Studies, 5 (1): 16-18. 